\title{
Binding of Human Factor VII and VIIa to Monocytes
}

\author{
George J. Broze, Jr., Division of Hematology/Oncology, Washington University \\ School of Medicine, Jewish Hospital of St. Louis, Missouri 63110
}

\begin{abstract}
A B S TRACT Human coagulation Factors VII and VIIa bind with equal affinity to monocytes stimulated with endotoxin. Equilibrium binding studies performed at $0^{\circ} \mathrm{C}$ using ${ }^{125} \mathrm{I}$-labeled Factor VII and VIIa showed the dissociation constant $\left(K_{\mathrm{d}}\right)$ to be $\simeq 82 \mathrm{pM}$ with $\simeq 3,600$ binding sites/monocyte. $\mathrm{Ca}^{++}$was required for Factor VII and VIIa interaction with monocytes (optimal $\mathrm{CaCl}_{2}$ concentration $\geq 2.5 \mathrm{mM}$ ) and binding was reversed by the addition of EDTA. The rate of conversion of Factor $\mathrm{X}$ to $\mathrm{Xa}$ in mixtures containing Factor VIIa and monocytes was directly related to the quantity of Factor VIIa bound to the monocyte surface. Thus the monocyte binding sites appear to represent tissue factor. Competition experiments showed that Factor VII and VIIa bind to the same monocyte sites and further, that unlabeled Factor VII and VIIa have the same affinity for the binding sites as the ${ }^{125}$ I-labeled proteins.
\end{abstract}

\section{INTRODUCTION}

Human Factor VII is a single chain, vitamin K-dependent serine protease present in plasma that can be converted to a two-chain form, Factor VIIa, by a number of agents including thrombin, Factor $\mathrm{Xa}$, and Factor XIIa (1). This conversion is associated with a $>24-$ 40 -fold increase in activity when measured in a onestage coagulation assay $(1-3)$.

Tissue factor is a lipoprotein cofactor that markedly enhances the proteolytic activity of Factors VII and VIIa upon Factors IX and X $(4,5)$. The activation of Factor X to Factor Xa by tissue factor and Factor VII or VIIa constitutes the classical "extrinsic" pathway of coagulation (6).

Tissue factor has been detected in many tissues and cultured cells including human fibroblasts $(7,8)$ and smooth muscle cells (9). Blood cells, however, lack significant tissue factor activity unless they are stimulated

This work was done during the tenure of a Clinician-Scientist Award from The American Heart Association.

Received for publication 9 March 1982 and in revised form 28 April 1982. by a variety of agents-for example, endotoxin (10), immune complexes (11), or complement C5a (12). Although granulocytes or lymphocytes were initially felt to produce this tissue factor activity, more recent studies have established the monocyte as its source (13-15).

In most studies of production of tissue factor by monocytes, total activity is measured following disruption of the cells by freeze-thawing or sonication. However, at least a portion of the tissue factor activity has been found to be available on whole, intact cells following their stimulation. By analogy with the reported binding of Factor Xa to platelets (16) through its cofactor, Factor $\mathrm{Va}$, it appeared possible that Factor VII or VIIa bind to tissue factor at the monocyte surface and there activate Factor X (and Factor IX).

Single chain, zymogen, Factor VII is unique among the vitamin $\mathrm{K}$-dependent proteases in that it appears to contain inherent coagulation activity. Recently, Nemerson et al. (17) have presented a cogent, albeit indirect, argument for this fact using bovine Factor VII and VIIa. Further, using a kinetic system involving the activation of Factor IX, they have shown that Factor VII and Factor VIIa have similar, if not identical, affinities for purified tissue factor.

We now show that human Factor VII and VIIa bind to the surface of stimulated, intact monocytes with essentially the same affinities and furthermore, that the binding of Factor VII or VIIa to monocytes is associated with the proteolytic activation of Factor X.

\section{METHODS}

Materials. Sterile, pyrogen-free water was obtained from Travenol Laboratories, Inc. (Deerfield, IL); Ficoll (type 400), bovine serum albumin (crystallized and lyophilized), bovine Factor VII/X-deficient plasma, rabbit brain cephalin, Trizma base, and Hepes from Sigma Chemical Co. (St. Louis, MO); polystyrene culture T-flasks from Corning Medical (Medfield, MA) and sodium Hypaque (50\%) from Winthrop Laboratories, New York. Sodium [ $\left.{ }^{125} \mathrm{I}\right]$ iodide, carrier free, was purchased from New England Nuclear (Boston, MA). All other chemicals were reagent grade or better products of Sigma Chemical Co., Fisher Scientific Co. (Pittsburgh, PA), or J. T. Baker Chemical Co. (Phillipsburg, NJ).

Solutions. Endotoxin-free water was used in all solutions, 
which were sterilized by passage through 0.2 or $0.45-\mu \mathrm{m}$ filters (Nalge Co., Nalgene Labware Div., Rochester, NY).

Ficoll-Hypaque: Ficoll, $57.34 \mathrm{~g}$ was dissolved in $180 \mathrm{ml}$ of sodium Hypaque (50\%) and $725 \mathrm{ml}$ of water.

Phosphate-buffered saline (PBS) ${ }^{1}: 1$ liter contained $0.2 \mathrm{~g}$ $\mathrm{KCl}, 0.2 \mathrm{~g} \mathrm{KH}_{2} \mathrm{PO}_{4}, 8.0 \mathrm{~g} \mathrm{NaCl}, 2.16 \mathrm{~g} \mathrm{Na}_{2} \mathrm{HPO}_{4} \cdot 7 \mathrm{H}_{2} \mathrm{O}$, and $1.0 \mathrm{~g}$ glucose, $\mathrm{pH} 7.4$.

PBS/EDTA: PBS with $1 \mathrm{mM}$ EDTA, pH 7.4.

PBS/HSA/EDTA: PBS/EDTA with $1 \mathrm{~g} /$ liter human serum albumin (American Red Cross Blood Services).

DMEM: powered Dulbecco's modified essential medium with L-glutamine (KC Biological, Inc., Lenexa, KS) was reconstituted with water and $\mathrm{NaHCO}_{3}$ according to manufacturer's instructions. Additional glucose and $1.0 \mathrm{M}$ Hepes were added so that the final concentrations were $4 \mathrm{~g} /$ liter glucose and $20 \mathrm{mM}$ Hepes, pH 7.4. Penicillin and streptomycin (Grand Island Biological Co., Grand Island, NY) were added to final concentrations of $50 \mathrm{U} / \mathrm{ml}$ and $50 \mu \mathrm{g} / \mathrm{ml}$, respectively.

HRB: Hepes resuspension buffer contained $0.15 \mathrm{M} \mathrm{NaCl}$, $0.02 \mathrm{M}$ Hepes, $\mathrm{pH} 7.4,1 \mathrm{~g} /$ liter glucose and $2 \mathrm{~g} /$ liter bovine serum albumin.

\section{Procedures}

Purification of cells. Human whole blood was obtained from donors following their informed consent. $480 \mathrm{ml}$ of blood were drawn into plastic syringes containing EDTA at a final concentration of $5 \mathrm{mM}(1.5 \mathrm{ml}$ of $0.2 \mathrm{M}$ EDTA- $\mathrm{NaOH}$, $\mathrm{pH} 7.5$, per $60 \mathrm{ml}$ syringe). Mononuclear cells and platelets were obtained by centrifugation over Ficoll-Hypaque (18), resuspended in $300 \mathrm{ml}$ of cold PBS/EDTA and centrifuged at $500 \mathrm{~g}$ in a Beckman J6-B centrifuge (Beckman Instruments, Inc., Spinco Div., Palo Alto, CA) for $10 \mathrm{~min}$. The cell pellets were resuspended in $50 \mathrm{ml}$ cold PBS/HSA/EDTA and washed again by centrifugation. This pellet was resuspended in $100 \mathrm{ml}$ of PBS/HSA/EDTA and placed on ice for elutriation.

Countercurrent elutriation was performed using a Beckman J21-B high-speed centrifuge equipped with a JE-6 elutriator rotor and strobe unit. A Cole-Parmer model 7013 Masterflex pump (Cole-Parmer Instrument Co., Chicago, IL) was used to control flow through the system which was monitored by a flow meter (model B-5684, Roger Gilmont Instruments, Inc., Great Neck, NY). Before each procedure, the entire system was washed extensively with ethyl alcohol (95\%), followed by sterile water, and finally cold PBS/HSA/ EDTA. The centrifuge was kept at $4^{\circ} \mathrm{C}$ and $400 \mathrm{~g}$ throughout.

By adjusting flow rates appropriately, lymphocytes and monocytes can be obtained using this elutriation system (19, 20 ). For the studies reported here, however, the goal was purification of monocytes alone, and an abbreviated elutriation schedule was used. The cell sample was loaded into the elutriation chamber at a flow rate of $9.4 \mathrm{ml} / \mathrm{min}$, followed by $250 \mathrm{ml}$ of PBS/HSA/EDTA at $9.4-10.5 \mathrm{ml} / \mathrm{min}$, and finally $150 \mathrm{ml}$ of buffer at $16 \mathrm{ml} / \mathrm{min}$. The cells elutriated at this final flow rate were collected by centrifugation and resuspended in DMEM. Minor changes in the flow rate during the washing stage were made depending upon the

${ }^{1}$ Abbreviations used in this paper: DMEM, Dulbecco's modified essential medium; HRB, Hepes resuspension buffer; HSA, human serum albumin; LPS, lipopolysaccharide; PBS, phosphate-buffered saline. level of the monocytes that could be directly visualized in the elutriation chamber.

For monocyte culture, T-flasks $\left(150 \mathrm{~cm}^{2}\right)$ were coated with $10 \mathrm{ml}$ of fetal calf serum for $1-7 \mathrm{~d}$ at $4^{\circ} \mathrm{C}$. $5 \mathrm{ml}$ of the fetal calf serum was then removed and $45 \mathrm{ml}$ of cells in DMEM and lipopolysaccharide (LPS) added such that the final concentration of cells was $1 \times 10^{6} / \mathrm{ml}$ and fetal calf serum $10 \%$. The $\mathrm{T}$-flasks were incubated at $37^{\circ} \mathrm{C}$ under $\mathrm{CO}_{2}$ $(10 \%)$ overnight $(16-18 \mathrm{~h})$. The cells were then eluted from the flasks by the addition of $0.2 \mathrm{M}$ EDTA-NaOH, pH 7.5 to a concentration of $5 \mathrm{mM}$ and further incubated at $37^{\circ} \mathrm{C}$ for 60-90 min (without agitation). The medium containing the eluted cells was poured from the T-flasks and the cells collected by centrifugation, resuspended in $50 \mathrm{ml}$ of cold PBS/ HSA/EDTA, again collected by centrifugation, and finally resuspended in DMEM at $1 \times 10^{7}$ monocytes $/ \mathrm{ml}$ and placed on ice.

The final preparations of cells used for these experiments contained $90-96 \%$ monocytes, $1-8 \%$ lymphocytes, $0-4 \%$ basophils, $<1 \%$ erythrocytes, $<1 \%$ neutrophils, and $<1 \%$ platelets. $75-85 \%$ of the cultured cells were eluted from the flasks using EDTA. Final yields of monocytes from $480 \mathrm{ml}$ whole blood ranged from 7 to $20 \times 10^{7}$ cells and were $>97 \%$ viable by trypan blue exclusion.

Identification of cells. Cells were identified by morphology and, initially, nonspecific esterase staining (alpha naphthylbutyrate or Sigma Histozyme kit 90-A1). Subsequently, neutral red was used, as it was faster, more convenient, and gave results very comparable $( \pm 2 \%)$ to nonspecific esterase staining $(21,22)$. 200 cells or more were examined to obtain a differential count.

LPS. LPS was a phenol extract of Escherichia coli 026:B6 or 055:B5 (Sigma Chemical Co.). Following resuspension in $0.15 \mathrm{M} \mathrm{NaCl}$ at a concentration of $5 \mathrm{mg} / \mathrm{ml}$, the suspension was sterilized by passage through a $0.45-\mu \mathrm{m}$ filter and stored at $4^{\circ} \mathrm{C}$. The concentration of LPS in the stock suspension was assumed to remain $5 \mathrm{mg} / \mathrm{ml}$ following filtration. The concentrations of LPS added to the cultures were chosen to stimulate maximal monocyte tissue factor production (10$40 \mu \mathrm{g} / \mathrm{ml})$.

Proteins. Factor VII was purified using a modification of a previously published method (3). Its molecular weight was assumed to be 48,000 (1) and an extinction coefficient $\left(A_{1 \mathrm{~cm}}\right.$ at $\left.280 \mathrm{~nm}\right)$ of 11.5 was estimated by the method of Babul and Stellwagen (23).

Factor $\mathrm{X}$ was purified essentially as previously described (24). Bovine Factor XIIa was a gift from Dr. K. Karachi and Dr. E. Davie (University of Washington, Seattle) and the Factor X coagulant protein from Russell's viper venom was a gift from K. Levine and Dr. C. Jackson (Washington University, St. Louis).

Crude human brain thromboplastin was prepared as previously described (1).

Iodination of Factor VII. Factor VII was labeled with $\left[{ }^{125} \mathrm{I}\right]$ iodide using a modification of the method of Fraker and Speck (25). $10 \mu \mathrm{g}$ of 1,3,4,6-tetrachloro-3a,6a-diphenylglycoluril (Iodo-gen, Pierce Chemical Co., Rockford, IL) in 100 $\mu$ l chloroform was dried in the bottom of a $12 \times 75-\mathrm{mm}$ polypropylene tube. $100-150 \mu \mathrm{l}$ of Factor VII, $1 \mathrm{mg} / \mathrm{ml}$, in $0.15 \mathrm{M} \mathrm{NaCl}, 0.02 \mathrm{M}$ sodium phosphate, $0.005 \mathrm{M}$ benzamidine, $0.001 \mathrm{M}$ EDTA, pH 7.0, was placed in the tube and 2.3-3.0 mCi (4-6 $\mu \mathrm{l})$ of carrier-free sodium [ $\left.{ }^{125} \mathrm{I}\right]$ iodide added. Following incubation for $15 \mathrm{~min}$ on ice with occasional agitation, the solution was removed from the tube and dialyzed two times against 1 liter of $0.15 \mathrm{M} \mathrm{NaCl}, 0.1 \mathrm{M} \mathrm{KI}$, $0.02 \mathrm{M}$ benzamidine, $0.02 \mathrm{M}$ Tris- $\mathrm{HCl}, \mathrm{pH} 7.5$ and then two times against 1 liter $0.15 \mathrm{NaCl}, 0.02$ Tris- $\mathrm{HCl}, \mathrm{pH} 7.5$. 
A portion of the radiolabeled Factor VII was converted to two-chain Factor VIIa by incubation $(100 \mu \mathrm{g} / \mathrm{ml})$ with $2 \%$ (wt/wt) of bovine Factor XIIa in $0.15 \mathrm{M} \mathrm{NaCl}, 0.02 \mathrm{M}$ Hepes, pH 7.4, with $1 \mathrm{mg} / \mathrm{ml}$ bovine serum albumin at $4^{\circ} \mathrm{C}$ for $48 \mathrm{~h}$. The iodinated single- and two-chain proteins were stored at a concentration of $1 \mu \mathrm{g} / \mathrm{ml}$ in $\mathrm{HRB}$ at $-70^{\circ} \mathrm{C}$.

In four iodination procedures the specific activity of the labeled Factor VII or VIIa ranged from 17,600 to 26,400 $\mathrm{dpm} / \mathrm{ng}$. In each instance, $>99.5 \%$ of the radioactivity was precipitated by $10 \%$ TCA. Functional, one-stage coagulation assays of Factor VII, pre- and immediately postiodination showed no change in activity ( 2 units $/ \mu \mathrm{g} \pm 10 \%$ ). Activation of labeled Factor VII to VIIa was associated with a 28-fold increase in activity. When the proteins were stored at a concentration of $1 \mu \mathrm{g} / \mathrm{ml}$ there was a gradual loss of functional activity, such that by 12 wk Factor VII had $50 \%$ and Factor VIIa $20 \%$ of its original activity when compared with unlabeled standards. If the labeled proteins were stored at higher concentrations, inactivation occurred considerably more rapidly. For the experiments presented here, the iodinated Factor VII and VIIa were used within 4 wk of the labeling procedure. Fig. 1 shows the activation of iodinated Factor VII to VIIa by Factor XIIa.

Binding assays. Although a centrifugation through oil technique, similar to that previously described for platelets (16) was initially planned to assay binding of Factor VII and VIIa to monocytes, it was found to be unsuitable. When these stimulated monocytes were spun through a mixture of $\mathrm{N}$ butyl phthalate/Apezion oil (9:1, density 1.028) it was evident both visually and by following specific radiolabeled Factor VII and VIIa binding that only a portion of the cells pelleted to the bottom of the tube as compared with cells centrifuged in the absence of oil. This problem was most marked at low monocyte concentrations $\left(<2 \times 10^{6} / \mathrm{ml}\right)$ and could be corrected by the inclusion of $1-2 \times 10^{8} / \mathrm{ml}$ platelets (but not lymphocytes or erythrocytes). Therefore, the two-

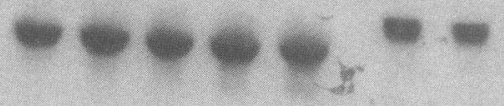

FIGURE 1 Activation of radiolabeled Factor VII to VIIa by bovine Factor XIIa. Factor VII $(100 \mu \mathrm{g} / \mathrm{ml})$ was activated with bovine Factor XIIa $(2 \mu \mathrm{g} / \mathrm{ml})$ in $0.15 \mathrm{M} \mathrm{NaCl}, 0.02 \mathrm{M}$ Hepes, $\mathrm{pH} 7.4$, with $1 \mathrm{mg} / \mathrm{ml}$ bovine serum albumin at $4^{\circ} \mathrm{C}$. SDS-polyacrylamide gel electrophoresis and autoradiography was performed on samples either unreduced (lanes 1$5)$ or reduced with $5 \% \beta$-mercaptoethanol (lanes 6-10), which were removed at $0,6,12,24$, and $48 \mathrm{~h}$ (left to right in figure). step centrifugation procedure described below was used in all experiments.

$200 \mu \mathrm{l}$ of monocytes $\left(1 \times 10^{7} / \mathrm{ml}\right)$ were added to $12 \times 75$ mm-polystyrene tubes containing $300 \mu \mathrm{l}$ of $\mathrm{HRB},{ }^{125} \mathrm{I}-\mathrm{Factor}$ VII or VIIa and $\mathrm{CaCl}_{2}$. Reaction mixtures routinely contained $4 \mathrm{mM} \mathrm{CaCl}_{2}$ and various concentrations of ${ }^{125} \mathrm{I}-\mathrm{Factor}$ VII or VIIa. The mixtures were incubated $60 \mathrm{~min}$ at $0^{\circ}, 20^{\circ}$, or $37^{\circ} \mathrm{C}$ and, following gentle resuspension, a $400-\mu l$ portion was transferred to $1.5-\mathrm{ml}$ polypropylene tubes and centrifuged for $2 \mathrm{~min}$ in a microfuge (Brinkmann Instruments, Inc., Westbury, NY) at ambient temperature. There was no detectable loss of cell viability during the incubation procedure itself as determined by trypan blue exclusion. 800 $\mu$ l of $N$-butyl phthalate was layered over the sample and the tube was centrifuged an additional 2 min. A $200-\mu l$ portion of the supernatant (now above the oil layer) was removed for determination of "free" Factor VII or VIIa and the remainder of the supernatant and $N$-butyl phthalate aspirated. The bottom of the tube containing the cell pellet was then cut off and counted for "bound" Factor VII or VIIa.

Nonspecific binding, as determined by the inclusion of $\mathbf{2 . 4}$ $\mu \mathrm{g} / \mathrm{ml}$ unlabeled Factor VII or VIIa in the reaction mixtures, was a constant fraction of total radioactivity added, and varied from 2.0 to $3.5 \%$. Specific binding was assumed to be the difference between the observed and nonspecifically bound radioactivity. Radioactivity was counted on a Searle model 1190 gamma counter (Searle Radiographics, Inc., Des Plaines, IL) with a counting efficiency of $50 \%$.

Coagulation assays. One-stage coagulation assays for Factor X and Factor VII or VIIa were performed as previously described $(1,16)$. To determine the rate of Factor $\mathrm{X}$ activation in the binding mixtures, a 200- $\mu$ l sample was removed, placed in a $12 \times 75-\mathrm{mm}$ polystyrene tube and 10 $\mu \mathrm{l}$ of Factor X (final concentration $8 \mu \mathrm{g} / \mathrm{ml}$ ) was added. At 30 -s intervals thereafter, $10-\mu 1$ samples were removed, diluted in $0.15 \mathrm{M} \mathrm{NaCl}, 0.02 \mathrm{M}$ Tris, pH 7.5, $0.001 \mathrm{M}$ EDTA, and $1 \mathrm{mg} / \mathrm{ml}$ bovine serum albumin (at least 50 -fold) and assayed as previously described for Factor Xa activity (16). A standard curve was constructed using Factor Xa produced from purified Factor X using 1\% (wt/wt) Factor X coagulant protein from Russell's viper venom.

The tissue factor assay was performed in a fibrometer (Becton, Dickinson \& Co., Rutherford, $\mathrm{NJ}$ ) at $37^{\circ} \mathrm{C} .60 \mu \mathrm{l}$ of Factor VIII-deficient plasma (George King Biomedical, Inc., Overland Park, KS), $60 \mu$ l of rabbit brain cephalin (19 dilution of stock suspension) and $60 \mu \mathrm{l}$ of the sample to be assayed diluted appropriately in $\mathrm{HRB}$ with $0.005 \mathrm{M}$ sodium citrate, were incubated $30 \mathrm{~s}$ at $37^{\circ} \mathrm{C}$. The reaction was then started by addition of $60 \mu \mathrm{l}$ of $25 \mathrm{mM} \mathrm{CaCl}_{2}$ at $37^{\circ} \mathrm{C}$. A standard curve was constructed using crude human brain thromboplastin and gave a linear relationship between clotting times and thromboplastin dilution on a log-log plot. The activity of the stock human brain thromboplastin was arbitrarily given a value of 10,000 units $/ \mathrm{ml}$ (a concentration of 200 units $/ \mathrm{ml}$ in the assay gave a clotting time of $19.5 \mathrm{~s}$ and a concentration of 1 unit $/ \mathrm{ml}$, a clotting time of $96 \mathrm{~s}$ ) The coagulant activity that developed in the monocytes following overnight incubation with LPS required Factor VII for expression.

To measure total tissue factor activity of the monocytes, the cells were lysed by sonication (15 short, 2-3-s bursts of sonication at a setting of 2.5 on a Branson model 350 sonifier, Branson Sonic Power Co., Danbury, CT, with the microtip probe) on ice.

Polyacrylamide gels. Sodium dodecyl sulfate (SDS) polyacrylamide gel electrophoresis was performed according to the method of Laemmli (26) with a $10 \%$ (ratio acrylamide/ 
bis, 37.5:1) separating gel and 4\% stacking gel (26). Autoradiography was performed in a cassette with Cronex (DuPont Instruments, Wilmington, DE) intensifying screens and XAR-5 (Eastman Kodak Co., Rochester, NY) x-ray film.

\section{RESULTS}

In preliminary experiments, no specific binding of Factor VII or VIIa could be detected to monocytes directly following their isolation from blood, or to cells incubated overnight in the absence of LPS. By $4 \mathrm{~h}$ following LPS stimulation, specific binding could be detected, but for convenience, the studies that follow were performed after overnight incubation of the monocytes. With LPS stimulation, the tissue factor activity of whole cells increased from $<1$ to 35.0 to 62.0 units $/ 1 \times 10^{6}$ monocytes by $16-18 \mathrm{~h}$ incubation. Assay of the cells following sonication showed total tissue factor activity to be $50-100$ units $/ 1 \times 10^{6}$ monocytes. In each instance, when the monocytes were cultured (Methods), the tissue factor activity available on whole cells was $40-100 \%$ of the total activity found following cell disruption. No specific Factor VII or VIIa binding to platelets or lymphocytes could be detected, either before or following their stimulation by LPS.

Incubations of monocytes with radiolabeled Factor VII or VIIa were routinely performed at $0^{\circ} \mathrm{C}$. This temperature was chosen to prevent further monocyte tissue factor production, inhibit possible confounding effects of cellular endocytosis, and inhibit adherance of the monocytes to the plastic test tubes (see below and Discussion).

Characteristics of Factor VII and VIIa binding to monocytes. Binding of Factor VII and VIIa to monocytes is time dependent, with maximal binding being obtained by $60 \mathrm{~min}$, even at concentrations of Factor VII or VIIa as low as $0.4 \mathrm{ng} / \mathrm{ml}$ (data not shown). At $0^{\circ} \mathrm{C}$ the binding of zymogen, single-chain Factor VII to monocytes is very similar to that of activated, twochain Factor VIIa (Fig. 2). That the binding observed using Factor VII was not due to its conversion to Factor VIIa during the incubation period itself was shown by SDS-polyacrylamide gel electrophoresis (under reducing conditions) and autoradiography of cell pellets during the time course experiment (Fig. 3). Further, when the activation of Factor $\mathrm{X}$ to $\mathrm{Xa}$ was determined in samples containing Factor VII, a delay in Factor $\mathrm{X}$ activation was observed, which presumably represented the feedback activation of Factor VII by Factor Xa (Fig. 4).

When similar experiments were performed at room temperature and $37^{\circ} \mathrm{C}$, binding in mixtures containing Factor VII and Factor VIIa was again very similar, but SDS-polyacrylamide gel electrophoresis of the cell pellets showed considerable conversion of Factor VII

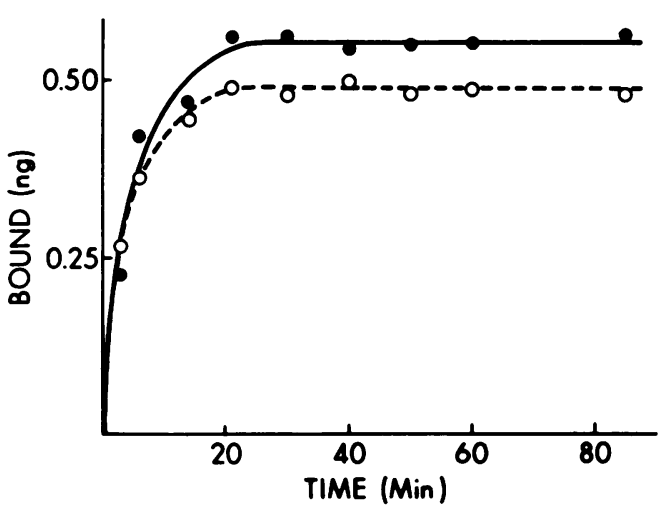

Figure 2 Time course of Factors VII and VIIa binding to monocytes. Mixtures containing $4 \times 10^{6} / \mathrm{ml}$ monocytes, 6 $\mathrm{ng} / \mathrm{ml}{ }^{125} \mathrm{I}-\mathrm{F}$ actor VII or VIIa and $4 \mathrm{mM} \mathrm{CaCl}_{2}$ were incubated at $0^{\circ} \mathrm{C}$ along with duplicate mixtures to which unlabeled Factor VII or VIIa $(2.4 \mu \mathrm{g} / \mathrm{ml})$, respectively, had also been added. Specific binding of Factor VII ( $\bullet$ ) and Factor VIIa $(O)$ is shown. Nonspecific binding in the Factor VII and VIIa mixtures was 16 and $19 \%$, respectively, of the total maximal binding.

to Factor VIIa during the 1-h incubation period. Whether this activation was related to a contaminating plasma protease, or one associated with the monocytes themselves, has not yet been determined.

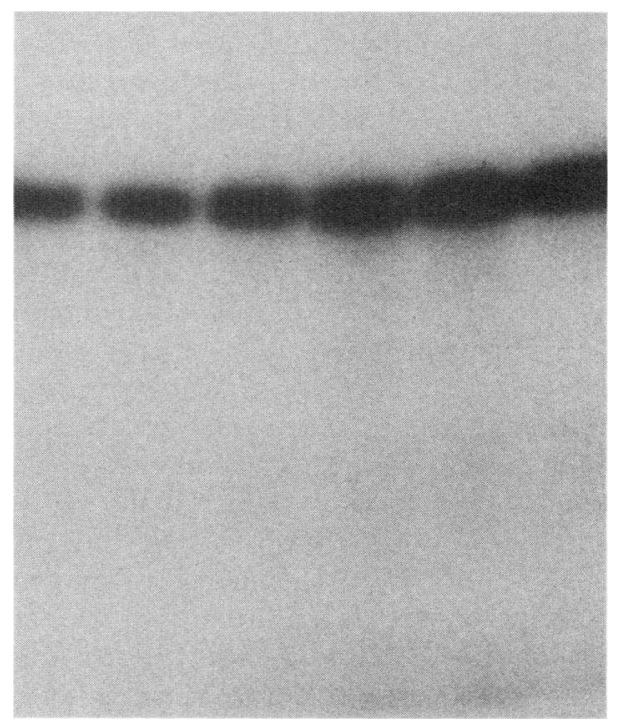

FIGURE 3 SDS polyacrylamide gel electrophoresis and autoradiography of bound Factor VII. Samples $(400 \mu \mathrm{l})$ from the ${ }^{125}$ I-Factor VII reaction mixture described in Fig. 2 were removed at $5,10,15,20,40$, and $60 \mathrm{~min}$ (left to right in figure) and centrifuged for $2 \mathrm{~min}$ in a microfuge. The cells were resuspended in $50 \mu \mathrm{l}$ of $0.15 \mathrm{M} \mathrm{NaCl}, 0.010 \mathrm{M}$ EDTA, $0.05 \mathrm{M}$ Tris, $\mathrm{pH} 8.1$, and $0.02 \mathrm{M}$ benzamidine, and centrifuged once again. A sample of each supernatant was reduced with $5 \% \quad \beta$-mercaptoethanol, and autoradiography performed following SDS polyacrylamide electrophoresis. 


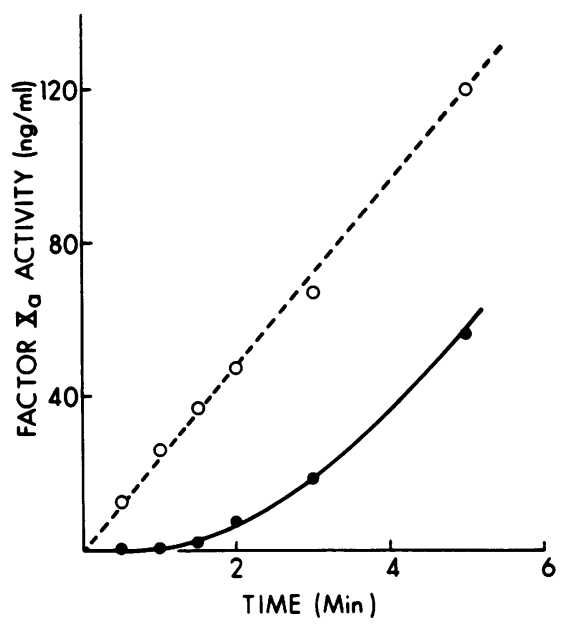

FIgURE 4 Factor $X$ activation in mixtures containing Factor VII or VIIa. At $20 \mathrm{~min}$ a $200-\mu \mathrm{l}$ sample was removed from each reaction mixture described in Fig. 2, kept at $0^{\circ} \mathrm{C}$ and activation of Factor $\mathrm{X}$ was determined (Methods). ${ }^{125} \mathrm{I}$-Factor VII mixture (O); ${ }^{125} \mathrm{I}-$ Factor VIIa mixture $(\mathrm{O})$

The binding of both ${ }^{125}$ I-Factor VII and VIIa could be reversed by the addition of either unlabeled Factor VII or Factor VIIa or by the chelation of calcium with EDTA. Fig. 5 shows the effect of adding a 100-fold excess of unlabeled Factor VIIa or EDTA (final concentration $5 \mathrm{mM}$ ) upon the binding of ${ }^{125} \mathrm{I}$-Factor VIIa. It is evident from the figure, that a portion of the nonspecific binding (that present in an excess of unlabeled Factor VIIa-see Methods) is calcium dependent. The reversal of binding by EDTA also indicates that endogenous Factor VII or VIIa, which may have bound to the monocytes during their preparation, was removed during the subsequent EDTA washing steps employed before the use of the monocytes in these binding experiments.

Fig. 6 shows the effect of $\mathrm{CaCl}_{2}$ upon Factor VIIa binding. Binding increased as the $\mathrm{CaCl}_{2}$ concentration approached $2.5 \mathrm{mM}$ and then remained constant. Experiments using Factor VII yielded the same results. Additional experiments showed that the amount of specific Factor VII or VIIa binding assayed in the reaction mixtures was directly related to the concentration of monocytes (tested in the range from 1 to 8 $\times 10^{6} / \mathrm{ml}$ ).

Equilibrium binding of Factor VII and VIIa to monocytes. The concentration dependence of ${ }^{125} \mathrm{I}$ Factor VII and VIIa binding to monocytes at $0^{\circ} \mathrm{C}$ is shown in Figs. 7 and 8 . In seven similar experiments the dissociation constant $\left(K_{d}\right)$ and amount bound per $4 \times 10^{6}$ monocytes for Factor VII was $3.96 \pm 1.06 \mathrm{ng} /$ $\mathrm{ml}(82.4 \mathrm{pM})$ and $1.14 \pm 0.22 \mathrm{ng}(3,500$ sites/monocyte) respectively (mean $\pm \mathrm{SD}$ ). In 10 experiments the $K_{\mathrm{d}}$ for Factor VIIa was $3.89 \pm 0.85 \mathrm{ng} / \mathrm{ml}(81 \mathrm{pM})$ and the

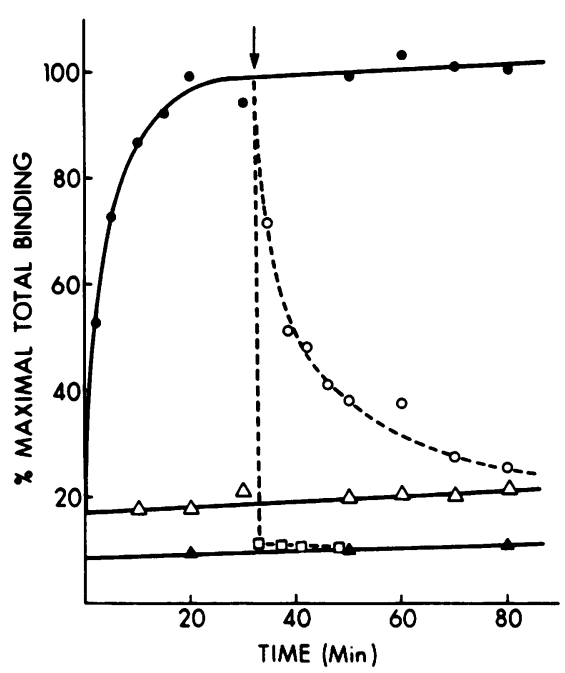

Figure 5 Reversal of ${ }^{125}$ I-Factor VIIa binding by the addition of unlabeled Factor VIIa or EDTA. A mixture containing $4 \times 10^{6} / \mathrm{ml}$ monocytes, $6 \mathrm{ng} / \mathrm{ml}{ }^{125} \mathrm{I}-\mathrm{Factor}$ VIIa and $4 \mathrm{mM} \mathrm{CaCl}$ was incubated at $0^{\circ} \mathrm{C}$ and total binding (๑) was determined at the time points indicated. At $32 \mathrm{~min}$ (arrow), two samples were removed. To one, unlabeled Factor VIIa (final concentration $600 \mathrm{ng} / \mathrm{ml}$ ) was added (O) and to the other EDTA (final concentration $5 \mathrm{mM}$ ) was added ( $\square$ ). Total binding in control mixtures in which the same concentration of unlabeled Factor VIIa $(\Delta)$ or EDTA $(\Delta)$ had been present from the onset are also shown. Total (100\%) binding represented $0.69 \mathrm{ng}{ }^{125} \mathrm{I}-\mathrm{F}$ actor VIIa/4 $\times 10^{6}$ monocytes.

amount bound per $4 \times 10^{6}$ monocytes was $1.19 \pm 0.18$ ng $(3,700$ sites/monocyte). To independently verify the $K_{d}$ obtained from the equilibrium binding experiments the second order association constant $\left(K_{2}\right)$ and first order dissociation constant $\left(K_{1}\right)$ were determined for Factor VIIa from the data presented in Fig. 5. The $K_{\mathrm{d}}$ calculated from these kinetic data $\left(K_{\mathrm{d}}=K_{2} /\right.$ $K_{1}$ ) was $88 \mathrm{pM}$, very similar to that obtained by equilibrium binding.

When the equilibrium binding experiments were performed at $37^{\circ} \mathrm{C}$, however, double-reciprical evaluation of the data consistently revealed curvilinear plots (concave upwards) (Figs. 7 and 8). This nonlinearity prevented calculation of dissociation constants, but the apparent saturation binding was always severalfold greater than that noted when the same cells were incubated at $0^{\circ} \mathrm{C}$. Intermediate results were obtained when the experiments were performed at $20^{\circ} \mathrm{C}$. This effect is being investigated further (Discussion).

To determine if the binding of Factor VIIa to monocytes was associated with its ability to activate Factor $X$, two experiments were performed. In the first experiment, a direct relationship between the rate of Factor $\mathrm{X}$ activation in the reaction mixtures and the quantity of Factor VIIa bound was demonstrated (Fig. 9 ). In the second experiment, the velocity of Factor 


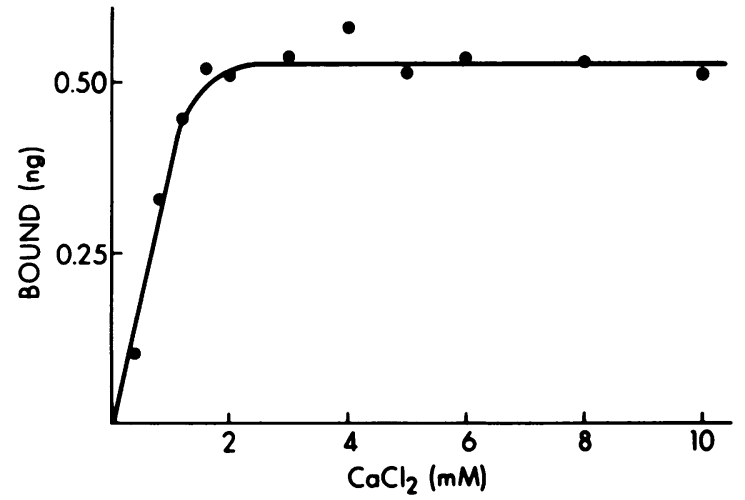

FIGURE 6 Dependence of ${ }^{125} \mathrm{I}-$ Factor VIIa binding upon calcium concentration. Mixtures containing $4 \times 10^{6} / \mathrm{ml}$ monocytes, $6 \mathrm{ng} / \mathrm{ml}^{125} \mathrm{I}-\mathrm{Factor} \mathrm{VIIa}$ and varying concentrations of $\mathrm{CaCl}_{2}$ were incubated at $0^{\circ} \mathrm{C}$. Duplicate mixtures containing additional unlabeled Factor VIIa (final concentration $2.4 \mu \mathrm{g} / \mathrm{ml}$ ) were used to determine nonspecific binding. After $60 \mathrm{~min}$, specific binding was determined per 4 $\times 10^{6}$ monocytes.

$\mathrm{X}$ activation in the whole reaction mixture $\left(4 \times 10^{6} /\right.$ $\mathrm{ml}$ monocytes, $6 \mathrm{ng} / \mathrm{ml}^{125} \mathrm{I}$-Factor VIIa, $4 \mathrm{mM} \mathrm{CaCl}_{2}$ at $20^{\circ} \mathrm{C}$ ) was compared with the velocities obtained in supernatants of the mixture separated from the cells by centrifugation at $12,000 \mathrm{~g}$ for $2 \mathrm{~min}$ in a microfuge (as in the binding studies), or at high speed $(105,000$ $g$ for $30 \mathrm{~min}$ ). The rate of Factor $\mathrm{X}$ activation in the supernatant following microfuge centrifugation was $4 \%$ of that of the whole mixture. Essentially no Factor $\mathrm{X}$ activation could be detected in the $105,000 \mathrm{~g}$ supernatant of the same reaction mixture. The converting activity present in the $12,000 \mathrm{~g} \times 2 \mathrm{~min}$ superna-

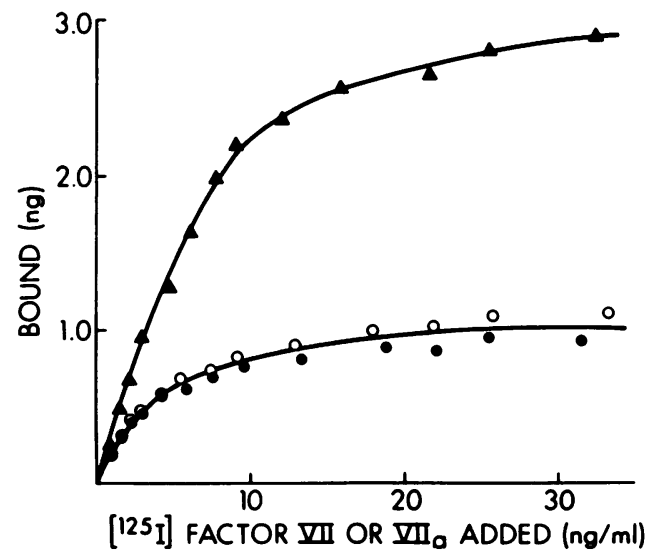

FIGURE 7 Equilibrium binding of ${ }^{125} \mathrm{I}$-Factor VII and VIIa to monocytes. Binding was determined as described in Methods. Specific binding at $0^{\circ} \mathrm{C}$ per $4 \times 10^{6}$ monocytes is plotted vs. the concentration of ${ }^{125} \mathrm{I}$-Factor VII (๑) or ${ }^{125} \mathrm{I}$-Factor VIIa (O). Specific binding of ${ }^{125} \mathrm{I}-$ Factor VIIa at $37^{\circ} \mathrm{C}$ is also depicted $(\mathbf{\Delta})$. tant was apparently "particle" bound as it could be removed by a centrifugation speed commonly used to sediment membranes. Although this activity could represent active monocyte secretion or membrane shedding (27), it appears as likely that it is related to mechanical manipulation of the monocytes during the in vitro incubation itself. The percentage of the total Factor Xa-converting activity, which remained in the microfuge supernatants, could be increased by raising the incubation temperature to $37^{\circ} \mathrm{C}$, or by repeated, vigorous agitation of the mixtures.

Competition between Factor VII and VII for their monocyte binding sites. To confirm that Factor VII and VIIa bind to the same monocyte sites, and with similar affinities, increasing concentrations of unlabeled Factor VII or VIIa were added to monocytes concomitantly with a constant amount of iodinated Factor VII or VIIa (final concentration $6 \mathrm{ng} / \mathrm{ml}$ ). After a 1 -h incubation at $0^{\circ} \mathrm{C}$, the amount of bound radiolabeled protein was determined. As shown in Fig. 10, unlabeled Factor VII and VIIa could compete with radiolabeled Factor VII or VIIa for the monocyte binding sites with essentially the same effectiveness. Furthermore, unlabeled Factor VII and VIIa inhibited the binding of radiolabeled Factor VII and VIIa with $K_{\mathrm{I}}$ very similar $(3-4 \mathrm{ng} / \mathrm{ml})$ to the $K_{\mathrm{d}}$ previously determined for the iodinated proteins. ${ }^{2}$

\section{DISCUSSION}

Before beginning the Factor VII and VIIa binding studies reported here, a number of experiments were performed to determine the optimal conditions for tissue factor production in monocyte cultures (data not shown). In agreement with previous reports, our preliminary experiments showed that monocytes, but not lymphocytes, neutrophils, or platelets produced tissue factor activity following stimulation with LPS. In contrast to other studies $(14,15,28,29)$, however, no dosedependent enhancement of monocyte tissue factor production was found when elutriator-purified lymphocytes were added to the monocyte cultures. As our monocyte preparations contained small numbers of lymphocytes (1-8\%), no comment can be made upon the claim that lymphocytes are absolutely required for stimulation of monocyte tissue factor production (15, 30 ). The addition of platelets to the monocyte cultures did enhance the amount of tissue factor activity produced (31). This effect appeared to be substantial when

\footnotetext{
${ }^{2} K_{1}=[\mathrm{II}]^{0.5} /\left(1+[\mathrm{L}] / K_{\mathrm{d}}\right)$ where $[\mathrm{I}]^{0.5}$ is the concentration of unlabeled Factor VII or VIIa giving $50 \%$ inhibition of binding of radiolabeled Factor VII or VIIa, [L] is the concentration of radiolabeled Factor VII or VIIa, and $K_{d}$ is the dissociation constant previously determined for the labeled proteins.
} 


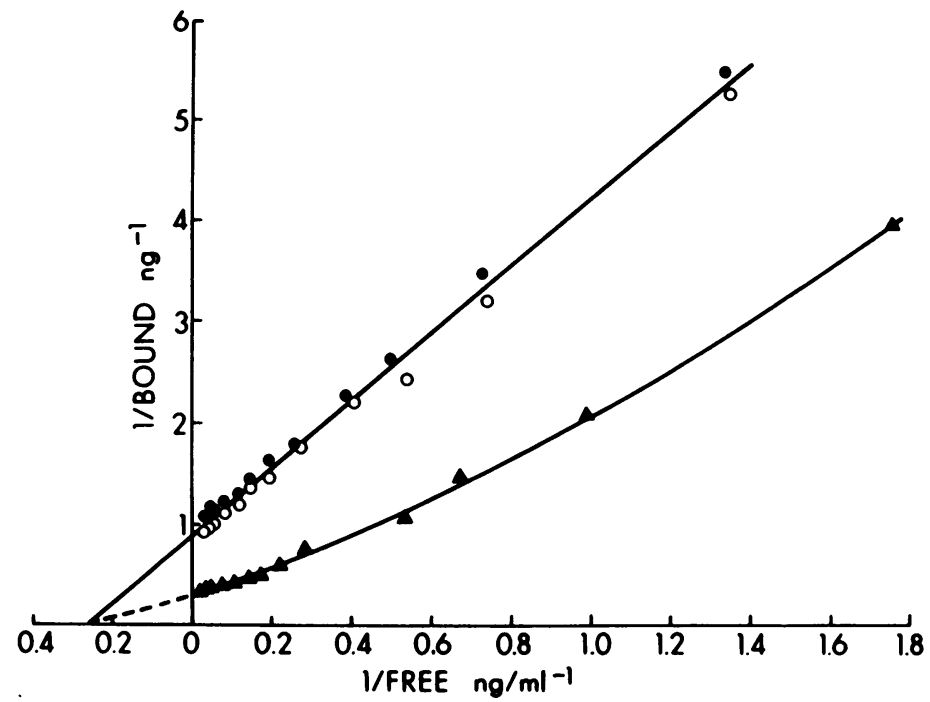

FigurE 8 Equilibrium binding of ${ }^{125}$ I Factor VII and VIIa to monocytes. Double reciprocal plot of the data presented in Fig. 7 .

a one-stage coagulation assay was used to determine tissue factor activity, but only modest (twofold in cultures containing $1 \times 10^{8}$ platelets and $5 \times 10^{5}$ monocytes per $\mathrm{ml}$ ) when a more specific, two stage, chromogenic assay, using purified Factor VIIa and Factor $\mathrm{X}$ was used. ${ }^{3}$ Because the presence of platelets in the monocyte cultures made subsequent elution of the monocytes considerably more difficult, cultures of monocytes alone were used for the binding studies.

With the use of indirect functional assays, the apparent calcium-dependent binding of Factor VII to crude tissue factor preparations $(5,32)$ and a human monocytic tumor cell line (33) has been reported previously. In fact, radioactively labeled bovine Factor VII has been used as a probe to localize tissue factor in tissue slices (34). Since the binding of Factor VIIa to the monocyte surface reported here was directly related to the velocity of subsequent Factor $X$ activation, in all probability (essentially by definition), the Factor VII and VIIa binding site represents tissue factor.

Equilibrium binding studies consistently yielded linear double-reciprical plots when they were performed at $0^{\circ} \mathrm{C}$. Curvilinear plots, however, were obtained when the same experiments were performed at $37^{\circ} \mathrm{C}$.

\footnotetext{
${ }^{3}$ The two stage, chromogenic assay for tissue factor activity was performed by incubating the sample to be tested with $100 \mathrm{ng} / \mathrm{ml}$ purified Factor VIIa, $6 \mu \mathrm{g} / \mathrm{ml}$ purified Factor $\mathrm{X}$, and $5 \mathrm{mM} \mathrm{CaCl}{ }_{2}$ at $37^{\circ} \mathrm{C}$. After $1 \mathrm{~min}$, the reaction was stopped by the addition of EDTA and a sample was diluted and assayed for Factor $\mathrm{Xa}$ activity with the chromogenic substrate S-2222 (Ortho Pharmaceutical, Raritan, NJ).
}

This phenomenon is being investigated further and preliminary experiments suggest it is not related to cellular endocytosis. The monocytes are metabolically active at $37^{\circ} \mathrm{C}$ and although "positive cooperativity" or possible "up regulation" of binding sites during the 60-min monocyte incubation period might be invoked to explain this phenomenon, a number of experiments are necessary to insure truly equilibrium conditions, to exclude ligand or receptor site degradation, and to rule out an artifactual effect of the in vitro binding assay itself. These studies are now under way.

The apparent equal affinity $\left(K_{d} \simeq 82 \mathrm{pM}\right)$ of both

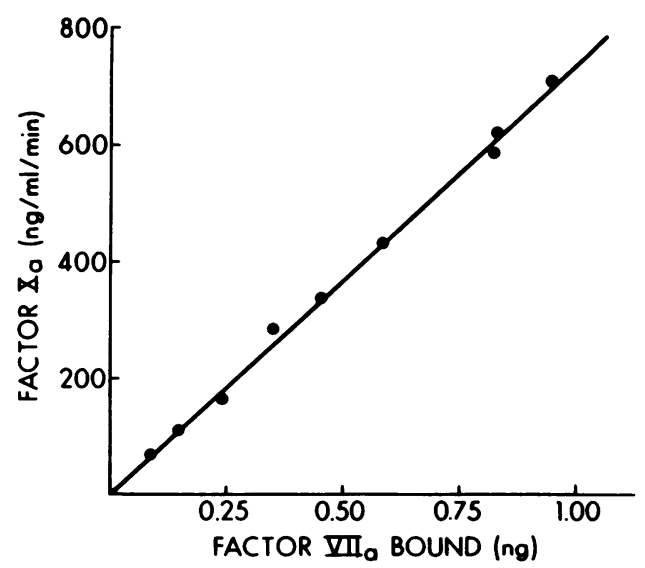

Figure 9 Correlation between ${ }^{125}$ I-Factor VIIa binding and activation of Factor X. Binding of ${ }^{125} \mathrm{I}$-Factor VIIa at $20^{\circ} \mathrm{C}$ and activation of Factor $X$ in the same mixtures were performed (Methods). Specific binding is shown per $4 \times 10^{6}$ monocytes. 


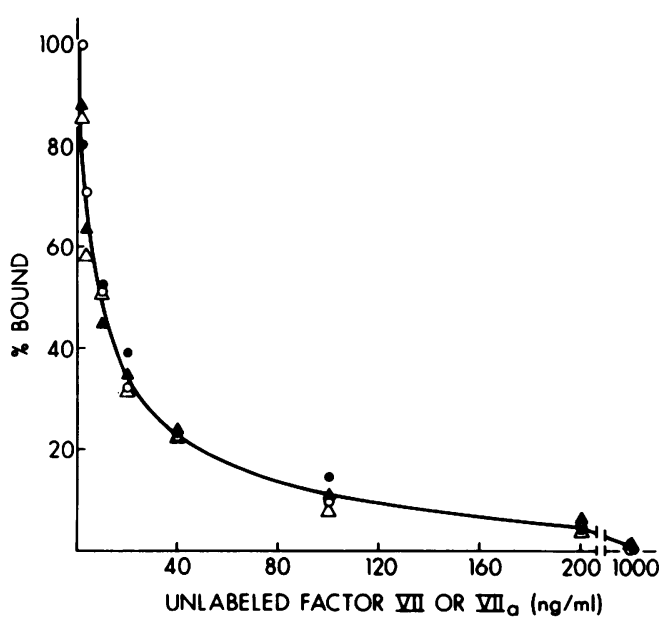

FIGURE 10 Inhibition of ${ }^{125}$ I-Factor VII and VIIa binding by unlabeled Factor VII or VIIa. Mixtures containing 4 $\times 10^{6} / \mathrm{ml}$ monocytes, $4 \mathrm{mM} \mathrm{CaCl}, 6 \mathrm{ng} / \mathrm{ml}^{125} \mathrm{I}-\mathrm{Factor}$ VII and increasing concentrations of unlabeled Factor VII (๑) or Factor VIIa $(O)$, and similar mixtures containing $6 \mathrm{ng} /$ $\mathrm{ml}{ }^{125} \mathrm{I}$-Factor VIIa plus increasing concentrations of unlabeled Factor VII $(\Delta)$ or Factor VIIa $(\Delta)$ were incubated at $0^{\circ} \mathrm{C}$. At $60 \mathrm{~min}$, specific binding was determined and plotted as a percentage of that bound in the absence of added, unlabeled Factor VII and VIIa. (100\% binding of ${ }^{125} \mathrm{I}-\mathrm{Factor}$ VII and VIIa was 0.52 and $0.58 \mathrm{ng}$, respectively, per $4 \times 10^{6}$ monocytes). Binding in mixtures containing $2.4 \mu \mathrm{g} / \mathrm{ml}$ unlabeled Factor VII or VIIa was assumed to represent nonspecific binding.

Factor VII and VIIa for their monocyte binding sites (presumably tissue factor) is unique among the known coagulation factors. Whether human Factor VII possesses intrinsic coagulation activity is unclear, as purified preparations undoubtably contain traces of Factor VIIa, and activation of Factor VII may occur during the assay procedure itself. This problem has been studied extensively in the bovine system by Nemerson and his colleagues (35-37), where it is apparent that bovine zymogen Factor VII possesses at most $<1 \%$ of the catalytic activity of activated Factor VII (17). Since zymogen Factor VII has only a fraction of the catalytic activity of Factor VIIa, but competes equally with Factor VIIa for monocyte binding (tissue factor), it would be predicted that the zymogen would function as an inhibitor of Factor X (or Factor IX) activation. Nemerson et al. (17) have recently described such zymogen inhibition in an in vitro system using bovine Factors VII and VIIa, purified tissue factor, and measurement of the velocity of Factor IX activation. Furthermore, these investigators found that diisopropyl fluorophosphate inactivated bovine Factor VII and VIIa, inhibited the activation of Factor IX by the Factor VIIa-tissue factor complex with very similar $K_{1 / 2}$ suggesting that they have essentially equal affinities for tissue factor (17). Thus, the direct binding exper- iments of human Factors VII and VIIa presented here are in agreement with kinetic experiments presented for the bovine factors.

If these in vitro studies can be applied to in vivo hemostasis, it would be anticipated that in areas where relatively low numbers of binding sites (i.e., less than the amount of tissue factor required to saturate the total Factor VII and VIIa) became available, singlechain Factor VII would dampen subsequent coagulation as its plasma level is $>400 \mathrm{ng} / \mathrm{ml}(1-3), 100$-fold above its $K_{I}$ for inhibition Factor VIIa binding to tissue factor. At larger wounds, however, where it is conceivable that sufficient tissue factor binding sites might be exposed to saturate the available Factor VII and VIIa, coagulation would proceed rapidly.

A number of proteases have been shown to activate Factor VII in purified, and in vitro plasma systems (38-42). The kinetically most efficient of these appears to be Factor $\mathrm{Xa}$, at least when purified reagents are used (38). Whether this is also the case in vivo, and further, the extent of Factor VII activation that occurs in vivo, is not clear. It is of interest, however, that when plasma is induced to clot in vitro by small amounts of tissue factor, Factors IX and VIII are required for optimal Factor $\mathrm{X}$ activation and thrombin generation (43-45). Along these same lines, the possible role of activated Factor VII as the Factor VIII bypassing activity in prothrombin complex concentrates has been suggested previously and is now being investigated further $(46,47){ }^{4}$

When the level of zymogen Factor VII is low, or the amount of Factor VII to Factor VIIa decreased, one would expect the dampening effect of Factor VII to be diminished. It is tempting to speculate that the loss of this inhibitory effect of zymogen Factor VII might contribute to the thrombotic complications associated with congenital Factor VII deficiency (48-50), loading dose coumarin therapy $(51,52)$, and infusion of prothrombin complex concentrates, which may contain high levels of activated Factor VII $(46,53-62)$.

\section{ACKNOWLEDGMENTS}

We would like to thank Darryl Higuchi for excellent technical assistance, Dr. J. Miletich and Dr. P. Majerus for helpful discussions, and B. Greene for assistance in preparation of this manuscript.

This work was supported, in part, by funds from the Missouri Affiliate of the American Heart Association.

\section{REFERENCES}

1. Broze, G. J., and P. W. Majerus. 1980. Purification and properties of human coagulation factor VII. J. Biol. Chem. 255: 1242-1247.

2. Bajaj, S. P., S. I. Rapaport, and S. F. Brown. 1981. Iso-

\footnotetext{
${ }^{4}$ Aronson, D. Personal communication.
} 
lation and characterization of human Factor VII. J. Biol. Chem. 256: 253-259.

3. Broze, G. J., and P. W. Majerus. 1982. Human Factor VII. Methods Enzymol. 80: 228-237.

4. Osterud, B., and S. I. Rapaport. 1977. Activation of Factor IX by the reaction product of tissue factor and Factor VII: additional pathway for initiating blood coagulation. Proc. Natl. Acad. Sci. U.S.A. 74: 5260-5264.

5. Nemerson, Y. 1966. The reaction between bovine brain tissue factor and Factors VII and X. Biochemistry. 5: 601-608.

6. Straub, W., and F. Duckert. 1961. The formation of the extrinsic prothrombin activator. Thromb. Diath. Haemorrh. 5: 402-404.

7. Zacharski, L. R., and O. R. McIntyre. 1973. Membranemediated synthesis of tissue factor (thromboplastin) in cultured fibroblasts. Blood 41: 679-685.

8. Maynard, J. R., C. A. Heckman, E. A. Pitlick, and Y. Nemerson. 1975. Association of tissue factor activity with the surface of cultured cells. J. Clin. Invest. 55: 814-824.

9. Maynard, J. R., B. E. Drayer, M. B. Stemerman, and F. A. Pitlick. 1977. Tissue factor coagulant activity of cultured human endothelial and smooth muscle cells and fibroblasts. Blood. 50: 387-396.

10. Lerner, R. G., R. Goldstein, and G. Cummings. 1971. Stimulation of human leukocyte thromboplastin activity by endotoxin. Proc. Soc. Exp. Biol. Med. 138: 145-148.

11. Rothberger, H., T. S. Zimmerman, H. L. Spiegelberg, and J. H. Vaughan. 1977. Leukocyte procoagulant activity: enhancement of production in vitro by IgG and antigen-antibody complexes. J. Clin. Invest. 59: 549557.

12. Muhlfelder, T. W., J. Niemetz, D. Kreutzer, D. Beebe, P. A. Ward, and S. I. Rosenfeld. 1979. C5 chemotactic fragment induces leukocyte production of tissue factor activity. J. Clin. Invest. 63: 147-150.

13. Rivers, R. P. A., W. E. Hathaway, and W. L. Weston. 1975. The endotoxin-induced coagulant activity of human monocytes. Brit. J. Haematol. 30: 311-316.

14. Edwards, R. L., F. R. Rickles. A. M. Bobrove. 1979. Mononuclear cell tissue factor: cell of origin and requirements for activation. Blood. 54: 359-370.

15. Levy, G. A., B. S. Schwartz, L. K. Curtiss, and T. S. Edgington. 1981. Plasma lipoprotein induction and suppression of the generation of cellular procoagulant activity in vitro. The requirements for cellular collaboration. J. Clin. Invest. 67: 1614-1622.

16. Miletich, J. P., C. M. Jackson, and P. W. Majerus. 1978. Properties of the Factor Xa binding site on human platelets. J. Biol. Chem. 253: 6908-6916.

17. Nemerson, Y., M. Zur, and R. Radcliffe. 1981. Initiation and control of coagulation by Factor VII, a zymogen. Blood. 58(Suppl. 1): 223a.

18. Boyum, A. 1968. Isolation of mononuclear cells and granulocytes from human blood. Scand. J. Clin. Lab. Invest. 21(Suppl. 97): 77-89.

19. Sanderson, R. J., F. T. Shepperdean, A. E. Vatter, and D. W. Talmage. 1977. Isolation and enumeration of peripheral blood monocytes. J. Immunol. 118: 1409-1414.

20. Fogelman, A. M., J. Seager, P. A. Edwards, M. Hokom, and G. Popjak. 1977. Cholesterol biosynthesis in human lymphocytes, monocytes, and granulocytes. Biochem. Biophys. Res. Commun. 76: 167-173.

21. Weston, W. L., R. D. Dustin, and S. K. Hecht. 1975. Quantitative assays of human monocyte-macrophage function. J. Immunol. Methods. 8: 213-222.

22. Norris, D. A., R. M. Morris, R. J. Sanderson, and P. F.
Kohler. 1979. Isolation of functional subsets of human peripheral blood monocytes. J. Immunol. 123: 166-172.

23. Babul, J., and E. Stellwagen. 1969. Measurement of protein concentration with interference optics. Anal. Biochem. 28: 216-221.

24. Miletich, J. P., G. J. Broze, and P. W. Majerus. 1980. The synthesis of sulfated dextran beads for isolation of human plasma coagulation factors II, IX, and X. Anal. Biochem. 105: 304-310.

25. Fraker, P. J., and J. C. Speck, Jr. 1978. Protein and cell membrane iodinations with a sparingly soluble chloramine, 1,3,4,6-tetrachloro-3a,6a-diphenylglycoluril. Biochem. Biophys. Res. Commun. 80: 849-857.

26. Laemmli, M. K. 1970. Cleavage of structural proteins during the assembly of the head of bacteriophage $T_{4}$. Nature (Lond.). 227: 680-685.

27. Muhlfelder, T. W., I. Khan, and J. Niemetz. 1978. Factors influencing the release of procoagulant-tissue factor activity from leukocytes. J. Lab. Clin. Med. 92: 65-72.

28. Edwards, R. L., and F. R. Rickles. 1980. The role of human $T$ cells (and $T$ cell products) for monocyte tissue factor generation. J. Immunol. 125: 606-609.

29. Levy, G. A., and T. S. Edgington. 1980. Lymphocyte cooperation is required for amplification of macrophage procoagulant activity. J. Exp. Med. 151: 1232-1244.

30. Osterud, B., J. Bogwald, U. Lindahl, and R. Seljelid. 1981. Production of blood coagulation Factor $V$ and tissue thromboplastin by macrophages in vitro. FEBS (Fed. Eur. Biochem. Soc.) Lett. 127: 154-156.

31. Niemetz, J., and A. J. Marcus. 1974. The stimulatory effect of platelets and platelet membranes on the procoagulant activity of leukocytes. J. Clin. Invest. 54: 1437-1443.

32. Zacharski, L. R., and O. R. McIntyre. 1971. Characterization of procoagulant produced in cell cultures by tests of coagulation. Thromb. Diath. Haemorrh. 26: 493-502.

33. Hudig, D., S. I. Rapaport, and S. P. Bajaj. 1981. Tissue factor-like activity of the human monocytic tumor cell line U937. Thromb. Haemostasis. 46: 33a.

34. Goldfarb, P. B., E. A. Pitlick, and Y. Nemerson. 1973. Factor VII: a biological probe for initiation sites of blood coagulation. J. Clin. Invest. 52: 34a.

35. Nemerson, Y., and M. P. Esnouf. 1973. Activation of a proteolytic system by a membrane lipoprotein: mechanism of action of tissue factor. Proc. Natl. Acad. Sci. U.S.A. 70: 310-314.

36. Radcliffe, R., and Y. Nemerson. 1976. Mechanism of activation of bovine Factor VII. J. Biol. Chem. 251: 4797-4802.

37. Zur, M., and Y. Nemerson. 1978. The esterase activity of coagulation Factor VII. Evidence for intrinsic activity of the zymogen. J. Biol. Chem. 253: 2203-2209.

38. Radcliffe, R., and Y. Nemerson. 1975. Activation and control of Factor VII by activated Factor X and thrombin. J. Biol. Chem. 250: 388-395.

39. Kisiel, W., K. Fujikawa, and E. Davie. 1977. Activation of bovine factor VII by Factor XIIa (activated Hageman factor). Biochemistry. 16: 4189-4194.

40. Laake, K., and B. Osterud. 1974. Activation of purified plasma Factor VII by human plasmin, plasma kallikrein, and activated components of the human intrinsic blood coagulation system. Thromb. Res. 5: 759-772.

41. Radcliffe, R., A. Bogdasarian, R. Colman, and Y. Nemerson. 1977. Activation of bovine Factor VII by Hageman factor fragments. Blood. 50: 611-617.

42. Seligsohn, U., B. Osterud, S. F. Brown, J. H. Griffin, and S. I. Rapaport. 1979. Activation of human Factor VII 
in plasma and in purified systems. J. Clin. Invest. 64: 1056-1065.

43. Biggs, R., and H. Nossel. 1961. Tissue extract and the contact reaction in blood coagulation. Thromb. Diath. Haemorrh. 6: 1-14.

44. Josso, F., and O. Prou-Wartelle. 1965. Interaction of tissue factor and Factor VII at the earliest phase of coagulation. Thromb. Diath. Haemorrh. 17(Suppl.): 3544.

45. Marlar, R. A., and J. H. Griffin. 1981. Alternative pathways of thromboplastin-dependent activation of human Factor X in plasma. Ann. N.Y. Acad. Sci. 370: 325-335.

46. Seligsohn, U., C. K. Kasper, B. Osterud, and S. I. Rapaport. 1979. Activated Factor VII: presence in Factor IX concentrates and persistence in the circulation after infusion. Blood. 53: 828-837.

47. Penner, J. A. 1981. Therapeutic approach to inhibitors: vitamin K-dependent factor concentrates. In Haemophilia. U. Seligsohn, A. Rimon, and H. Horoszowski, editors. Alan R. Liss, Inc., New York. 97-105.

48. Godal, H. C., K. Madsen, and R. Nissen-Meyer. 1962. Thromboembolism in patients with total proconvertin (Factor VII) deficiency. Acta Med. Scand. 171: 325-327.

49. Hall, C. A., S. I. Rapaport, and S. A. Anees. 1964. A clinical and family study of hereditary proconvertin (Factor VII) deficiency. Am. J. Med. 37: 172-181.

50. Gershwin, M. E., and J. K. Gude. 1973. Deep vein thrombosis and pulmonary embolism in congenital Factor VII deficiency. N. Engl. J. Med. 288: 141-142.

51. Koch-Weser, J. 1968. Coumarin necrosis. Ann. Intern. Med. 68: 1365-1366.

52. Faraci, P. A., R. A. Deterling, Jr., A. M. Stein, H. R.
Rheinlander, and R. J. Cleveland. 1978. Warfarin-induced necrosis of the skin. Surg. Gynecol. Obstet. 146: 695-700.

53. Tullis, J. L., M. Melin, and P. Jurigan. 1965. Clinical use of human prothrombin complexes. N. Engl. J. Med. 273: 667-674.

54. Kasper, C. K. 1973. Postoperative thromboses in hemophilia B. N. Engl. J. Med. 289: 160.

55. Blatt, P. M., R. L. Lundblad, H. S. Kingdon, G. McLean, and H. R. Roberts. 1974. Thrombogenic materials in prothrombin complex concentrates. Ann. Intern. Med. 81: 766-770.

56. Mardusi, S. L., and R. Burney. 1974. Prothrombin complex concentrates and thromboses. N. Engl. J. Med. 290: 403-404.

57. Kasper, C. K. 1975. Thromboembolism complications. Thromb. Diath. Haemorrh. 33: 640-644.

58. Edson, J. R. 1974. Prothrombin-complex concentrates and thromboses. N. Engl. J. Med. 290: 403.

59. Menache, D. 1976. Report of the task force on the clinical use of Factor IX concentrates. Thromb. Haemostasis. 35: 748-750.

60. Cedarbaum, A. I., P. M. Blatt, and H. R. Roberts. 1976. Intravascular coagulation associated with the use of human prothrombin complex. Ann. Intern. Med. 84: 683687.

61. Schimpf, K. L., K. Zimmerman, and B. Kompf. 1976. DIC and postoperative wound bleeding under Factor IX substitution therapy in a case of hemophilia B: successful treatment with heparin. Thromb. Res. 8: 65-70.

62. Daucy, R. J., G. G. Shashaty, and C. E. Rath. 1976. Acute coagulopathy following infusion of prothrombin-complex concentrates. Am. J. Med. 60: 719-722. 